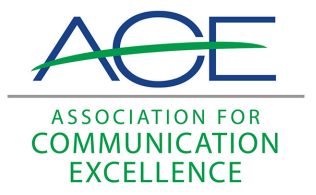

Journal of Applied Communications

\title{
The Teaching Portfolio; The Handbook of Technical Writing: Form and Style; Technical Writing: A Reader-Centered Approach ; Learning to Use Simplified English: A Preliminary Study
}

Debrah H. Jefferson

Robert G. Hays

Carol Sanders Reiner

Follow this and additional works at: https://newprairiepress.org/jac (c) (i) (2) (2)

This work is licensed under a Creative Commons Attribution-Noncommercial-Share Alike 4.0 License.

\section{Recommended Citation}

Jefferson, Debrah H.; Hays, Robert G.; and Reiner, Carol Sanders (1992) "The Teaching Portfolio; The Handbook of Technical Writing: Form and Style; Technical Writing: A Reader-Centered Approach ; Learning to Use Simplified English: A Preliminary Study," Journal of Applied Communications: Vol. 76: Iss. 1. https://doi.org/10.4148/1051-0834.1480

This Review is brought to you for free and open access by New Prairie Press. It has been accepted for inclusion in Journal of Applied Communications by an authorized administrator of New Prairie Press. For more information, please contact cads@k-state.edu. 


\title{
The Teaching Portfolio; The Handbook of Technical Writing: Form and Style; Technical Writing: A Reader-Centered Approach ; Learning to Use Simplified English: A Preliminary Study
}

\author{
Abstract \\ Book and article reviews of The Teaching Portfolio, by Peter Seldin; The Handbook of Technical Writing: \\ Form and Style, by Mary Lee, Gloria Stephenson, Max Anderson and Lynn Allen Lee; and Technical Writing \\ : A Reader Centered Approach, by Paul V. Anderson; Learning to Use Simplified English: A Preliminary \\ Study, Margaret Thomas, Gloria Jaffe, J. Peter Kincaid and Yvette Stees in Technical Communication;
}


Jefferson et al.: The Teaching Portfolio; The Handbook of Technical W riting: Form a

\section{Reviews}

The Teaching Portfollo. Peter Seldin. 1991. Boston, Massachusetts: Anker Publishing Company, Inc., paperback, 91 pages. approximately $\$ 17$.

The quality of academic teaching has recelved national attention in recent years, More than 10,000 studles, according to Peter Seldin, have been published on teaching effectiveness. They indicate effective teachers, among other tralts, are knowledgeable, onganbed, elearly state information, motlvate students, and show imagination. But how do those tralts get translated into a document that supports your efforts for promotion, tenure, or these days, finding a new poslition?

A promising solution, according to Seldin, is the "teaching portfollo," In The Tooching Fortfolo, Seldin documents the process of putting a teaching portfollo together and provides examples of portfollos from diffenent disciplines.

It is an organlzed way to doeument all aspects of a faculty member's teaching. It should contain current evaluations as well as selective documents supporting the faculty member's teaching performance, that involves the process of teaching and its contents as well as the results. In essence, the portiolio is used to demonstrate how teaching is carried out.

As professlonal communicators. we are famillar with the portiolio concept as a useful tool for displaying communications material. However. It ts a new tool for the academiclan. Seldin says the portiollo can be used to: (1) gather and present hand evidence and specific data about teaching effectiveness: (2) provide structure for self-reflection: (3) course syllabi. curriculum development, collect and summarbe evaluatlons: (4) provide peer evaluations and consultation notes; (5) provide student evaluations: (6) document articles and talks presented on instruction; and $(7)$ to advise faculty regarding improvement in their teaching. For elther advisement or evaluation. the portiolio can include videos of teaching.

Those ACE members on academic appointments may find it increasIngly dimeult to translate non-eredit courses and training or instruction into understandable terms for the regular faculty who sit on hiring. promotion, or tenure committes. The portifllo could help translate your performance In to something understandable by showing how research results were used to develop a training program, publication, press release, or video script, for example.

If you are in the job market, you probably have nun into requests for student evaluations and other evidence of teaching ablity. Across the country. as well as Canada, about 100 colleges and unlversitles are experimenting with varlous forms of portfollos, In essence. the trend for documenting teaching ablity is growing. But for many. the only proof at hand showing them to be eredible instructors may be student course evaluation forms. Student evaluattons do not, according to Selin. provide sufficient information for accurate evaluation of teaching performance. Promotion and tenure committees often do not know how to evaluate 
teaching when they examine credentuals on scholarship and professional activity from diverse programs and teaching methods, Seldin (Seldin and Annis, The Journal of Stafl Program and Organkation Development, 1990. p. 197) sayss, "At bottom, perhaps. the core problem is the lack of hard information and evidence about the quality of teaching performance."

To get atarted, Seldin advises the instructor to evaluate what is taught In relationship to the Instructor's personal goals and projectlons. He cautions the instructor to be selective because the portiflio is a vehicle that does more than Just show and tell what has been accomplished. By using samples from several instructors, Seldin is able to show the versatility of the portfolio approach in his 90 -page publication. The first 25 pages contain basic informatlon with the rest containing sample materials.

Unlike the production portfolio of the graphic designer. this teaching portfollo looks at measures of effectiveness, teaching responsibilities, peer reviews and notes, and samples of personal writing on instruction (objectwes, goals, articles). The actual length of portfollo's narrative may only be 5 to 7 pages with samples in an appendix. The length is short because its contents only involve your statements on teaching objectives, goals, summaries of evaluations or peer consultations, and your elforts at self improvement in teaching. Actual syllabl and reading lists, asslgnments and exams, handouts, student evaluations. video or audio samples of teaching plus other support items go in the appendix.

For ACE members ready to move up or out, the teaching portiolio may be a useful tool. An abbrevlated verston of the book is provided in The Joumal of Stad/ Program and Onganization Development. 1990.)

Debrah H. Jefferson University of Missouri-Columbia

\section{The Fandbook of Technical Writing: Form and Style. Mary Lec, Glorla Stephenson, Max Anderson, and Lynn Allan Lee. 1990. San Dlego: Harcourt Brace Jovanovich (HBJ), paperback, 487 pages including Index, approximately $\$ 25$.}

This book is similar to many standard handbooks on English grammar in format, and to a point, content. It stresses the essentuals of grammar. punctuation, mechanles, diction, and sentence structure. It goes beyond the standard text, however, by including material specifle to sclentific and technical writing and drawing ecamples from varlous types of technical and sekntile communication.

The first half of the book is devoted to the tools of grammar, Including seven sectlons on sentence structure alone. The rest of the work deals with the "Larger Elements." These include business letters, memos, job-hunting correspondence, abstracts and summaries, reports, proposals, gephics. and more. These latter sections make this publication a useful reference for professlonal writers.

In their preface, the authors imply that this handbook is intended equally bor students and prolessionals. That was a noble goal, but the book https://newprairiepress.org/jac/vol76/iss1/11 
probably is weaker because of It. One result is that the two halves seem to be almed at different audiences.

As a grammar text, this handbook doesn't measure up to several others that are widely used in college writing courses. As a technical writing text. It isn't nearly as good as Paulv. Anderson's Technical Writhg, also published by HEJ.

Sull. The Handbook of Technical Writing could be of significant walue to professionals dealing with scientific and technical subject matter. Publicatons editors will find Its chapter on graphles useful, particularly the sections on construeting tables and charts and on effectve diagrams and tlustrathons. Chapters on reports and proposals also are likely to be espectally useful. The latter chapter includes a comprehensive proposal for project funding that serves effectlvely as a general model.

One practical aspect of this book that is a real strength is the "key point" summary that begins each chapter. These often include, specifically or by implication, "Know your audience." That's a very good starting polnt for any discussion of writung.

Robert G. Hays University of Illinols

\section{Technical Writing: A Reader-Centered Approach (Second Bdl- tlon). Paul V. Anderson. 1991. San Dlego: Harcourt Brace Jovanovich, paperback, 824 pages Including Index, approximately $\$ 35$.}

This book is developed on a simple but important premise: "Writing at work differs from writing at school." Even though it is intended primarly ass a text book. Technical Writing bullds on this premlse in ways that make it quite valuable as a reference for professional writers who deal with technical subject matter.

In the second edition, Anderson has added new chapters on persuastve writung. using the library (including computerized bibliographies). and collaboratwe writing, as well as case-study problems. All are Important additions.

The title accurately reflects the author's main advice. "When writing:he says, "think constantly about your readers," He emphas bes the personal dimension of writing throughout the book.

Anderson insists that written communication, to be successful, must affect the indwdual to whom it is addressed, In specine ways. This is the essence of his reader-centered approach. He oflers no magic formula. merely a process that begins with "defining your communication objectives" and continues through final revision.

Samples of reader-centered writing are easy to come by. Anderson offers resumes and job application letters as an introductory form. He also provides general frameworks, he calls them "superstruetures." for several other types, including reports of various kinds, proposals, and instructions.

Technical Writong devotes a full 16 chapters to detalled discussion of the writing process. These extend to visual alds and page destgn. One entire 
chapter is devoted to word cholce.

This book has a pleasing emphasls on revlewing evaluation, and testing communication objectwes. It pays less attention to revising material once It is written, but does offer helpful guldelines. Correcting mechanleal problems, the author warns, always hends the list: The working world is very intolerant of them, particularly errors in spelling and basic grammar."

Anderson prowdes chaplers on collaborative writung and preparing and delivering oral presentations. These, like the rest of the book, emphasize the reader-centered approach to communication.

Tochutcal Writing to a thick book, more than 800 pages, with valuable appendlces and a comprehensive Index. It is amply lllustrated and includes appropriate ecamples of most of the types of technical communication it eovers.

If I were teaching a course In technical writing this probably would be my cholce for a text. Beyond that, I recommend it as a worthy addition to the professional communicator's reference shelf.

Robert G. Hays University of nlinots

"Learning to Use Simpllfed English: A Prellminary Study," by Margaret Thomas, Glorla Jaffe, J. Peter Kincald, and Yvette Stees In Technical Communication: Journal of the Soclety for Technical Communication, (First Guarter, February 1992), Soclety for Technleal Communlcation, 815 Fifteenth St. N.W., Washington, D.C. 20005 , p. 69-73.

Documents written in "Simplifed English" (SE) are caster to read than those written in standard English, especlally for readers whose first language is not English. Because writing in simplifed Engllsh is dificult for experienced technical writers, the University oicentral Florida is developing a soltware tool, the Simplined English Analyoer (SEAN). to help writers prepare documents in SE. The authors report on researeh conducted to see how accurately writers detect volations of SE writing rules and what sort of mistakes are likely when text is rewritten in SE. The research shows that while SE is easy to understand, it is dimcult to write without a lot of tritining and practuce. Training tools such as SEAN can ease the procedure. The authors describe the software package under development.

The importance of simplified English grows as business and industry become more global because English already is the second language for many world ctikens, Considerable interest has been shown in "Controlled English" as the Ingua franci of technical applications because of the time, cost, and personnel necessary for muluple high-quality transhations. Computer-based programs facilitate the trainingof writers by providing individuallzed feedback.

What Is Controlled Endluh?

Controlled English refers to writing systems that contain limited cholces of standard English words. These systems restrlet acceptable sentence

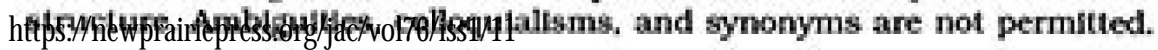
DOI: $10.4148 / 1051-0834,1480$

Journal of Applled Communientions, Vol. 76, No. 1. 1992/61 
Consequently. non-English readers can understand technical documents written in Controlled English after relatively brlef training.

Controlled English can be traced to C. K. Okden. In the 1900 and 1940s, he hoped to popularke a general purpose "Basie English" that would be an International language as well as serve as a foundation for standard English. A dictlonary whs published including some 20,000 common words defined in terms of an 850-word Baske English vocabulary. However, basic English was a novelty that never got of the ground.

In the 1970s, controlled Endlish was used in technleal writing. In 1971 . the Caterpllar Tractor Company developed a 900 -word voctbulary it used for writung product documentation for worldwide distribution. In 1979. the Doudas Areraft Company devised a 2,000 word dietlonary it uses for Its technieal manuals.

\section{What Io Simplified English?}

SE is one type of Controlled English developed for technical use by the Asscetation Europeene des Constructeurs de Materiel Aerospatial and the Acrospace Industrles Assoclatjon. It Includes a core vocabulary of 1.500 words and a set of 40 wrting rules for style and grammar. Each word has only one meaning and can be used as only one part of speech. Technical names or names of manufacturing processes can be added when necessary. SE was developed for writing documentation on alreraft malntenance.

\section{Writing in SE}

Writers skllied In English with an extensive voxabulary have dimculty Writing in SE because they must learn to restrict their syntax and vocabu. lary. To help writers overcome this diffeulty. The Unversity of Central Florida's Insutute of SImulation and Training is developing SEAN, software which monitors compllance with SE writing rules and use of the approved vocabulary. Some rules are subjective and cannot be automated, but SEAN can incorporate one-half of them. When the prodram fags a word that is not part of the SE vocabulary. It consults a reverse thesaurus and suggests an SE alternative. The thesaunus conslsts of a database of approdimately 15.000 non-SE words. It has a paraing routine that detects the misuse of a word with respect to tis allowed part of speech.

What is interesting are not the particulars of the study, but the parameters of almplifled English and how we can use them to make our publicutions more rendly understood. Notice how closely the SE Writing Rules (below) parallel what seasoned journalists learn from crusty editing prolessors or clty editors.

\section{Croupling Worda}

1. Break up noun clusters that have more than three nouns.

2. If posstble. put an artlele or a demonstrative adjecthe before a noun. Verbe

1. Use the following verb forms:

- Infinitive

- present tenge

* past tense

- simple future tense

- past participle as an adjective

2. Do not use the "bng" form of the verb.

3. Use the active volce. 
4. Do not use the pust participle with a helping verb to make a complex verb.

Sentence Length

1. The maxdmum length of a sentence is 20 words.

2. To determine sentence length, the colon and the dash count as a full stop, each word in a hyphenated group counts as a word, text within parenthesis is a separate sentence.

slmplifled English

Ceneral

1. Write only one instruction per sentence, uniless two actlons must be done at the same time.

2. Write the verb in the imperatlve foommanding) form for Instructions and warnings.

3. If you start an instruction with a dependent clause, you must separate that statement from the rest of the fnstruction with a comma.

4. Do not leave out a verb to make a sentence shorter.

Bven though test subjects had coples of the rules, they overlooked rule violations. mandatory commas after introductory clauses, and the Imperative verb form in instructions, One quarter of the time, they falled to nolice the passwe volce and nonallowed verb tenses/forms. Also, the subjects missed the stralphtforward adherence to the word count 37 percent of the time. The highest level of accuracy was the detectlon of noun clusters; only eight percent were missed.

Notice the difference between the unediled version and the SE version of the following sample.

Unedited - Place the water heater in a clean, dry location as near as pratetleal to the area of greatest heated water demand. Long uninsulated hot water lines can waste energy and water. Clearance for accessibllity to permit Inspection and servicing such as removing heading elements or checking controls must be provided.

SE Vervion - Put the water heater in a clean, dry location near the area where you use the most hot water. If the hot water lines are long and they do not have insulatton. you will use too much energy and water. Make sure you have aceess to the heating elements and the controls for inspection and servicing.

The sample sibe was small (11). and the participants were advanced technical writing students, not experienced professionals. Students reinforced the assertion that SE. whlle easy to understand, is dimcult to write. Adherence to the writing rules improved with training. Much training time is necessary for writers to become fuent in any controlled English system. but SEAN has the potential to lessen that time. The authors belleve that SEAN is a valuable training ald that will be helpful in meeting the future needs of international communication.

The simplined English article is part of a special section. "Communicating With and Through Computers." The section contalns 11 articles, most of interest to writers and editors who Interact with a computer. 